\title{
Scanning Electron Microscopy Reveals Different Response Pattern of Four Vitis Genotypes to Xylella fastidiosa Infection
}

Felix B. Fritschi, Division of Plant Sciences, University of Missouri, Columbia 65211; Hong Lin, United States Department of Agriculture-Agricultural Research Service, Crop Diseases, Pests \& Genetics Research Unit, Parlier, CA 93648; and M. Andrew Walker, Department of Viticulture and Enology, University of California, Davis 95616

\begin{abstract}
Fritschi, F. B., Lin, H., and Walker, M. A. 2008. Scanning electron microscopy reveals different response pattern of four Vitis genotypes to Xylella fastidiosa infection. Plant Dis. 92:276-286.

The xylem-limited bacterium Xylella fastidiosa causes Pierce's disease (PD), whose disease symptoms are primarily the result of xylem vessel blockage in susceptible grapevines. Stem internode and petiole tissues from infected and uninfected control plants of four grape genotypes (Vitis vinifera, V. rufotomentosa, V. smalliana, and V. arizonica/candicans) differing in PD susceptibility were examined using scanning electron microscopy (SEM). Tyloses, fibrillar networks, and gum plugs were observed in lumens of tracheary elements in petioles and internodes of both water-inoculated control plants and X. fastidiosa-inoculated plants of all genotypes. Bacteria were not observed in control plants. In both petiole and internode tissues, the greatest number of occluded xylem vessels were observed in $V$. vinifera and the smallest number in $V$. arizonica/candicans. The number of xylem vessels infested with $X$. fastidiosa was greatest in $V$. vinifera and did not differ among the other three genotypes. Systemic infection was found in all genotypes. The frequency with which $X$. fastidiosa infested vessels were observed using SEM corresponded well with bacterial levels estimated by enzyme-linked immunosorbent assay. Among infected plants, tylose formation in internodes was lowest in $V$. arizonica/candicans and did not differ among the other three genotypes. Infection with $X$. fastidiosa strongly induced tylose formation in V. vinifera and V. smalliana but not in V. arizonica/candicans. Analysis across tissues and genotypes indicated an induction of fibrillar networks and gum occlusions in response to $X$. fastidiosa infection, whereas treatment comparisons within genotypes were not significant except for $V$. vinifera petioles. Limiting the spread of $X$. fastidiosa infection by xylem conduit occlusions does not appear to be the mechanism conferring PD resistance or tolerance to $V$. arizonica/candicans, $V$. smalliana, or $V$. rufotomentosa. In contrast, the strong induction of tyloses may be detrimental rather than beneficial for $V$. vinifera survival after $X$. fastidiosa infection.
\end{abstract}

Pierce's disease (PD) is a bacterial disease that affects grapevines and is capable of devastating entire vineyards $(21,33)$. The causal agent, Xylella fastidiosa, is a gram-negative bacterium transmitted by xylem-feeding insects vectoring the pathogen among a broad range of host plant species $(6,21)$. Infection of susceptible grapevines with $X$. fastidiosa results in xylem vessel occlusions by bacterial aggregates, tyloses, and gums $(18,20,28$, 30,46). As the disease develops, increasing vessel occlusion progressively impairs water movement, which commonly is

Corresponding author: H. Lin

E-mail: hlin@fresno.ars.usda.gov

Mention of a trademark or proprietary product does not constitute a guarantee or warranty of the product by the U.S. Department of Agriculture and does not imply approval or the exclusion of other products that may also be suitable.

Accepted for publication 20 September 2007.

doi:10.1094/PDIS-92-2-0276

This article is in the public domain and not copyrightable. It may be freely reprinted with customary crediting of the source. The American Phytopathological Society, 2008. thought to result in the typical PD symptoms $(15,16,26,27)$. However, to date, a definitive proof that water stress is the cause for symptom development and eventual death of susceptible plants has not been established. In contrast, a recent publication by Thorne et al. (49) compared the symptomology of PD-infected plants under well-watered and water-deficit conditions as well as various water-deficit treatments. None of the water-deficit treatments resulted in symptoms matching those of PDinfected plants; therefore, the authors suggest that factors other than water deficit may cause symptom development, bringing renewed attention to other possible mechanisms of pathogenesis such as phytotoxins, generation of growth regulator imbalances, and programmed cell death which were suggested previously $(10,19$, $25,29)$. Typical symptoms of PD include low vigor, marginal leaf necrosis, abnormal stem maturation manifested as "green islands," as well as "matchsticks" formed by the retention of petioles after leaf lamina have separated $(46,47,49)$.

PD is endemic to the southeastern states of the United States and has been implicated as the primary factor limiting the grape industry in those areas (19). Numer- ous studies have identified a range of wild grape species that exhibit various degrees of resistance to PD $(11,12,20,23,31,43,48)$. However, most of these studies were based on examination of vine longevity, disease symptomology, and levels of $X$. fastidiosa in the plant. More detailed investigations into the nature of the pathogen-host interaction are necessary to identify possible reasons for the differential sensitivity of various genotypes. The apparently xylemlimited nature and spread of $X$. fastidiosa through the xylem vessels make this vascular tissue a prime target for further investigations.

General grapevine anatomy, including that of the vascular tissue, has been investigated by various researchers $(14,32$, $34,35)$. Studies also have investigated various anatomical aspects related to PD development $\quad(8,17,28,30,45,47,49,50,52)$. Generally, these studies were conducted with one susceptible (usually Vitis vinifera) or one resistant (usually Muscadinia rotundifolia) grape genotype. Information available for other genotypes characterized in respect to their PD susceptibility is very limited. Krivanek et al. (24) reported on xylem vessel occlusion by tyloses for six field-resistant and two $V$. vinifera genotypes, and Mollenhauer and Hopkins (30) compared M. munsoniana to $V$. vinifera and $M$. rotundifolia in respect to the presence of bacteria, tyloses, and gums. The main objectives of this study were to examine the type and extent of xylem vessel occlusion as well as the percentage of vessel colonization by $X$. fastidiosa in stems and petioles of four Vitis genotypes previously identified to support a range of $X$. fastidiosa levels.

\section{MATERIALS AND METHODS}

Plant material. Four grape genotypes (V. arizonica/candicans b43-17, V. rufotomentosa DVIT 1416, V. smalliana B02SG, and $V$. vinifera Chardonnay) were propagated from herbaceous cuttings obtained from grapevines in the vineyards of the University of California, Davis. The cuttings were rooted in cellulose sponges on intermittent mist beds with $27^{\circ} \mathrm{C}$ bottom heat. Rooted cuttings first were transplanted into small $15.6-\mathrm{cm}^{3}$ plastic pots with soil consisting of a 1:1:1 mixture of Yolo sandy loam, perlite, and peat, and 4 weeks later into 1-liter plastic pots. Vigorously growing plants were pruned to two 
buds to normalize shoot growth. After cutback, plants were grown for about 6 weeks prior to inoculation. The plants were grown in a greenhouse with supplemental lighting to maintain an average day-andnight cycle of 18 and $6 \mathrm{~h}$, respectively, and temperatures between 20 and $32^{\circ} \mathrm{C}$. Plants were irrigated automatically twice per day using a system with 1.9-liter/h emitters set for $2 \mathrm{~min}$ and adjusted as necessary to accommodate increasing requirements of the growing plants. Every 3 weeks, plants were fertilized with $50 \mathrm{ml}$ of diluted Miracle-Gro $(\mathrm{N}: \mathrm{P}: \mathrm{K}=15: 30: 15$; Scotts, Marysville, $\mathrm{OH})$. As plants reached about $1 \mathrm{~m}$, lateral and apical shoot tips were pruned every 4 weeks to increase light penetration into the canopy as well as air circulation.

Bacterial culture and plant inoculation. About 6 weeks after cut-back, plants were inoculated with either a strain of $X$. fastidiosa originally isolated from the Stag's Leap area of Napa Valley, California or double-distilled (dd) $\mathrm{H}_{2} \mathrm{O}$ in the case of control plants. The $X$. fastidiosa inoculum was prepared by isolating the bacteria from symptomatic Chardonnay plants maintained in the greenhouse. The bacteria were grown on solid periwinkle wilt medium at $29^{\circ} \mathrm{C}(6,7)$ and washed from the culture plates with $\mathrm{ddH}_{2} \mathrm{O}$ after about 10 days. Stems were inoculated as described by Krivanek et al. (23). A 10- $\mu$ l droplet of bacterial suspension, adjusted to $6 \times 10^{8}$ $\mathrm{CFU} / \mathrm{ml}$ (absorbance at $600 \mathrm{~nm}=0.25$ ), was placed $10 \mathrm{~cm}$ above the base of the stem, and a needle was pushed through the droplet and into the stem. To ensure success, each plant was inoculated twice. The second inoculation was followed immediately by the first around the same location of stem. Piercing of the stem resulted in the uptake of the inoculum into the transpiration stream.

Enzyme-linked immunosorbent assay. Leaf blades excised from the petioles used for scanning electron microscopy (SEM) analysis and stem internode tissue harvested near the location of the section utilized for microscopy were used to quantify $X$. fastidiosa levels. Determination of $X$. fastidiosa concentrations were accomplished by enzyme-linked immunosorbent assay (ELISA) as described by Krivanek and Walker (23) and are only outlined here. For each genotype and tissue, a separate standard curve was generated by diluting $X$. fastidiosa in plant tissue extracts from healthy plants to concentrations of $6.5 \times 10^{6}, 3.25 \times 10^{6}, 6.5 \times 10^{5}, 3.25 \times$ $10^{5}, 6.5 \times 10^{4}$, and $3.25 \times 10^{4} \mathrm{CFU} / \mathrm{ml}$. Extracts from $X$. fastidiosa-free tissue served as negative controls. All samples, negative controls, and standard curves were run in duplicate. Concentrations per gram of plant tissue were established by conversion of the predicted concentrations per milliliter of extract.

Sample collection, preparation, and SEM. Stem and petiole samples were col- lected 16 weeks post inoculation from three $X$. fastidiosa-inoculated plants and two water-inoculated plants of each species. Both tissues were sampled from the bottom, middle, and top positions of each plant. The bottom position comprised the $25-\mathrm{cm}$ segment of the plant immediately above the point of inoculation, and the middle and top positions consisted of the following two $25-\mathrm{cm}$ segments. Multiple cross sections were cut from each petiole and stem position and were fixed in formalin-alcohol-acetic acid (44) for a minimum of $48 \mathrm{~h}$. Prior to cryofracturing, the specimens were infiltrated for at least $30 \mathrm{~min}$ with an aqueous solution of $30 \%$ glycerol serving as cryoprotectant. A steel plate, serving as working surface, and a razor blade were precooled in liquid $\mathrm{N}$ and used to prepare cross sections by fracturing the specimens immediately after immersion in liquid N. Sections were dehydrated in a series of ethanol solutions $(30,50,70,90$, and $100 \%$ ) and critical-point dried in carbon dioxide (Autosamdri 815B; Tousimis Research Corporation, Rockville, MD). Dried specimens were mounted on aluminum stubs with colloidal graphite, sputter coated with gold (SPI-Module Sputter Coater, Structure Probe, Inc. West Chester, PA), and examined in a Hitachi S-3500N SEM (Hitachi High-Technologies America, Schaumburg, IL). The standard operating condition of the SEM was $10 \mathrm{kV}$; occasionally, however, conditions were adjusted in the range of 5 and $20 \mathrm{kV}$ to optimize observations. Energy dispersive $\mathrm{X}$-ray analysis (EDAX) was conducted using a detector with a QDD Violin Detector ( $8-\mu \mathrm{m}$ beryllium window) and VIDX Scan Active Digital Imaging software (EVEX Analytical, Princeton, NJ). For

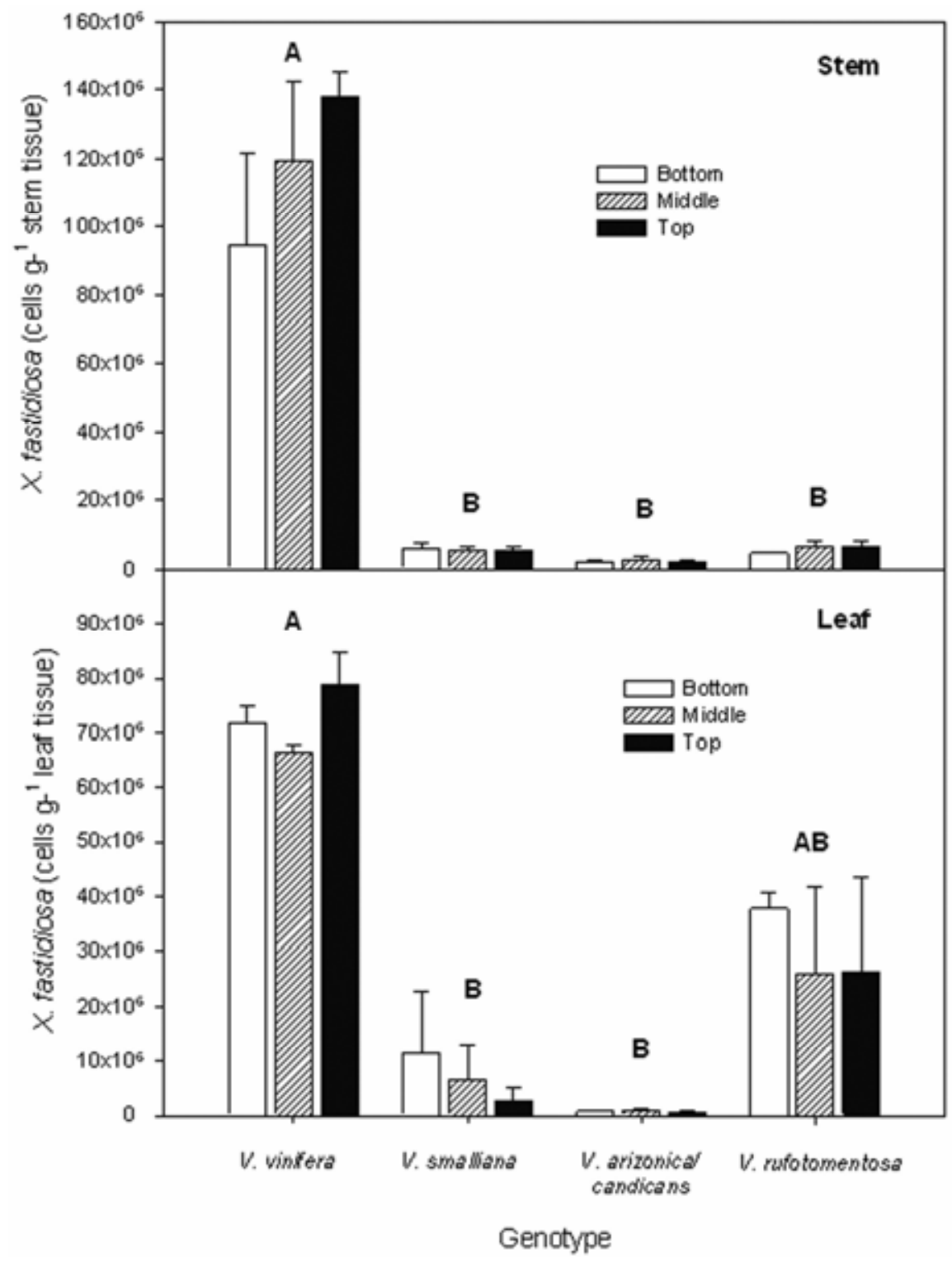

Fig. 1. Concentration of Xylella fastidiosa, as determined by enzyme-linked immunosorbent assay, in stems and leaves from the bottom, middle, and top positions of the three plants examined for each genotype. Error bars represent standard error of the mean. Different letters between genotypes indicate significant differences in $X$. fastidiosa levels across positions within tissue. 
EDAX, the microscope was operated at an acceleration voltage of $20 \mathrm{kV}$, a working distance of $17.8 \mathrm{~mm}$, an elevation angle of $40^{\circ}$, and a magnification of $\times 2,500$. The spectra were acquired for $120 \mathrm{~s}$ (live time) and a dead time of $2 \%$.

Vessel occlusion analysis. From each sample, three cross sections were analyzed as follows. In all, 50 randomly selected xylem vessels from a minimum of five vascular bundles in petioles and numerous ray-delimited sectors in stem internodes were examined for occlusion to determine the degree and type of occlusion. Thus, a total of 150 xylem vessels was scrutinized and used to calculate an average for each sample, resulting in a total of 450 vessels examined each for internode and petiole tissues of one plant. For each genotype, 2,700 vessels were examined for the infected plants and 1,800 vessels for the control plants. Because individual X. fastidiosa cells and small colonies as well as initials of other occlusions can be difficult to observe, every vessel was examined systematically at magnifications between $\times 800$ and 3,000 , focusing up and down the vessel interior. The type of occlusion present was determined and the extent of occlusion was categorized into three groups: (i) $<25 \%$, (ii) 25 to $50 \%$, and (iii) $>75 \%$ occlusion of a particular vessel.

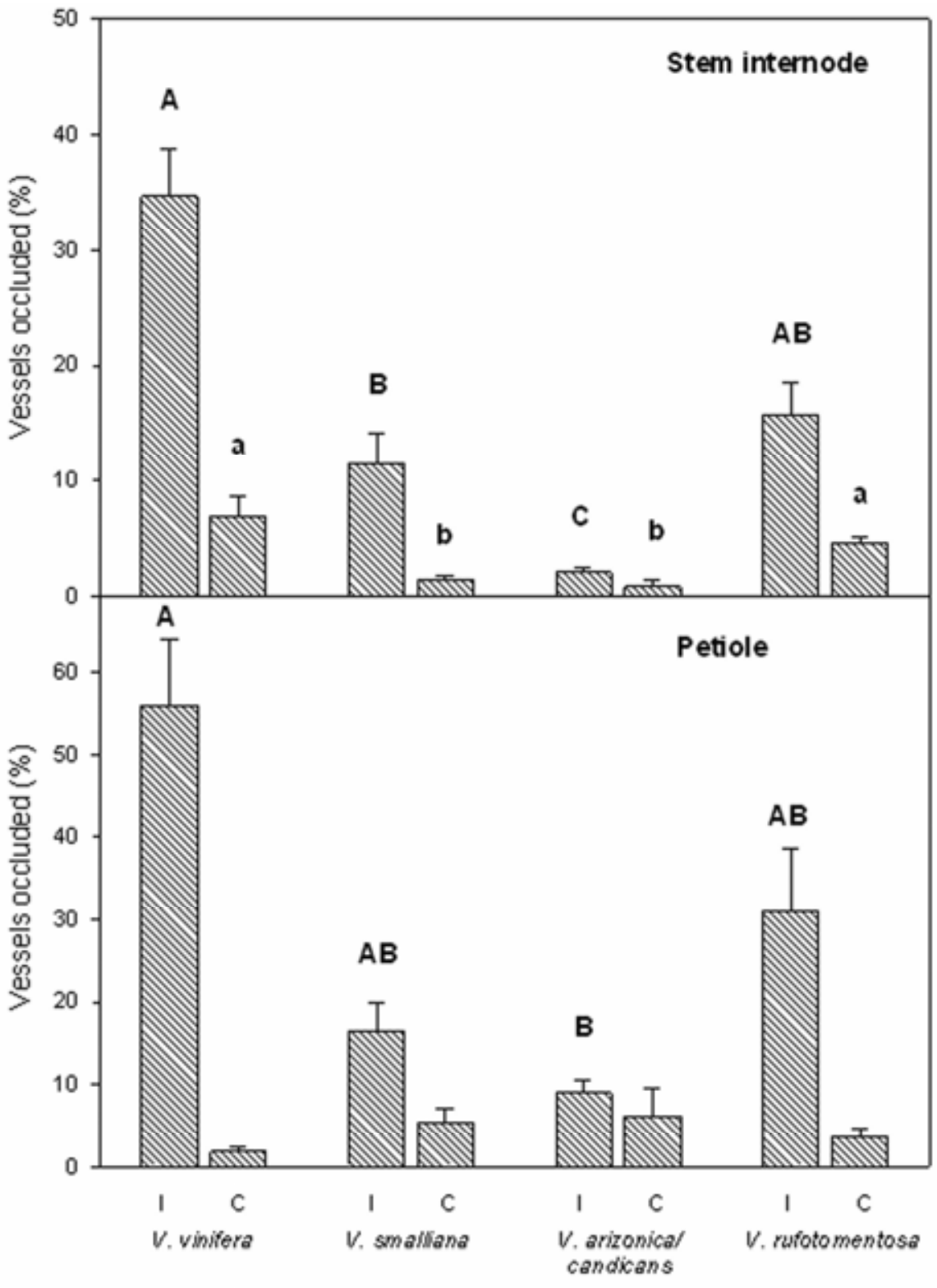

\section{Genotype and Infection Status}

Fig. 2. Comparison of the percentage of xylem vessels containing occlusions among the four grape genotypes examined. Error bars indicate the standard error of the means. Different letters between genotypes indicate significant differences in percentage of xylem vessel occlusion within tissue. Comparisons were made within infection status, capital letters corresponding to infected plants and noncapital letters to control plants. Absence of letters indicates that the differences were not statistically significant.
Experimental design and statistical analyses. The plants were arranged in a completely randomized design, with each individual plant representing an experimental unit. Three X. fastidiosa-inoculated plants and two control plants were maintained for each genotype. For statistical analyses of ELISA results, bacterial concentrations were natural log-transformed. The SAS software package (version 9.1; SAS Institute, Cary, NC) was used to analyze the data using the June 2006 release of PROC GLIMMIX which employs a generalized, linear, mixed-model approach. Overall data were analyzed as a split-split plot model, with genotype and infection status as main plots, section as the subplot, and tissue as the sub-subplot. Bonferroni adjustment was used for treatment comparisons. Regression analyses were conducted using PROC REG.

\section{RESULTS}

Symptomology. The onset of early PD symptoms such as marginal chlorosis as well as chlorotic areas away from the margins occurred 6 weeks post inoculation in $V$. vinifera plants. Follow-up observations 2 months post inoculation revealed typical symptoms for $\mathrm{PD}$, including marginal leaf necrosis and chlorotic transition zones on leaves from the bottom and middle sections of $V$. vinifera plants. At the time of sample collection (16 weeks post inoculation), advanced symptoms, including entirely necrotic leaf blades, green islands, and matchsticks, were observed on the $V$. vinifera plants. In contrast, green islands and matchstick symptoms were not observed in the other three genotypes. Some leaf necrosis symptoms were observed in $V$. smalliana and $V$. arizonica/candicans; however, they occurred to a similar extent in water- and $X$. fastidiosa-inoculated plants. In $V$. rufotomentosa, leaf necrosis was observed about three times more frequently in $X$. fastidiosa- compared with water-inoculated plants but did not reach the extent observed in $V$. vinifera.

ELISA. The concentration of $X$. fastidiosa was significantly affected by genotype in both stem and leaf tissues $(P<$ 0.01; Fig. 1). In contrast, $X$. fastidiosa concentrations were not significantly affected by the plant section examined. For stem tissues, the differences were significant between $V$. vinifera and the other genotypes. Among the other genotypes, no differences were observed between $V . r u$ fotomentosa and $V$. smalliana; however, tendencies toward greater levels of $X$. fastidiosa in $V$. rufotomentosa $(P=0.052)$ and $V$. smalliana $(P=0.072)$ than $V$. arizonica/candicans were found. For leaf blades, $X$. fastidiosa levels in $V$. vinifera were significantly greater than in $V$. smalliana $(P=0.01)$ and $V$. arizonical candicans $(P<0.01)$. However, large variation in the $X$. fastidiosa concentrations in $V$. rufotomentosa leaf blades re- 
sulted in the absence of significant differences between it and the other three genotypes. The average concentration in $V$. vinifera leaves was $7.2 \times 10^{7} \mathrm{CFU} \mathrm{g}^{-1}$ and, in stems, $1.17 \times 10^{8} \mathrm{CFU} \mathrm{\textrm {g } ^ { - 1 }}$. X. fastidiosa levels in the leaves and stems of $V$. arizonica/candicans did not exceed the positive threshold (mean of control + three standard deviations) employed in this study. In contrast, the $X$. fastidiosa concentrations in $V$. smalliana and $V$. rufotomentosa exceeded the positive threshold but were much lower than in $V$. vinifera. The average concentrations of $X$. fastidiosa in $V$. smalliana were $7.0 \times 10^{6} \mathrm{CFU} \mathrm{g}^{-1}$ in leaves and $5.8 \times 10^{6}$ $\mathrm{CFU} \mathrm{\textrm {g } ^ { - 1 }}$ in stems. Those in $V$. rufotomentosa were $30.0 \times 10^{6} \mathrm{CFU} \mathrm{g}^{-1}$ in leaves and $6.1 \times 10^{6} \mathrm{CFU} \mathrm{g}^{-1}$ in stems.
SEM. Examination of xylem vessels using SEM revealed the presence of various types of occlusions in both water- and $X$. fastidiosa-inoculated plants of all genotypes. Tyloses, fibrillar networks, gums, and, on very rare occasions, crystals were observed in both control and $X$. fastidiosainfected plants and contributed to xylem vessel occlusions. Statistical analysis of
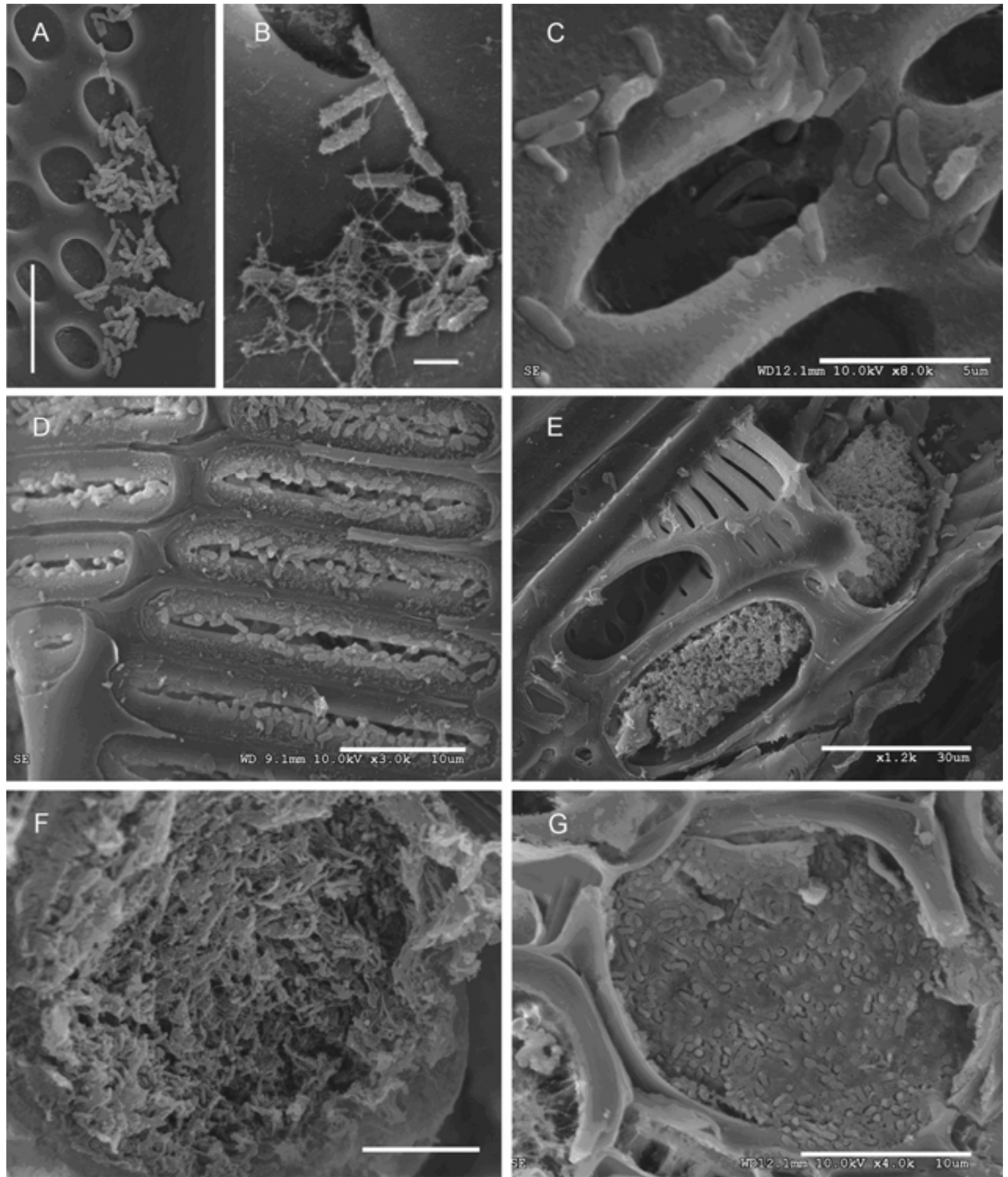

Fig. 3. Scanning electron micrographs of Xylella fastidiosa-infested xylem vessels of internodes and petioles of infested Vitis vinifera plants. A, Loosely arranged small aggregates of $X$. fastidiosa lining the cell wall next to and in pits of a xylem vessel. Bar $=10 \mu \mathrm{m}$. B, Small aggregate of bacteria attached to the cell wall and connected to each other by fibrillar strands. Bar $=2 \mu \mathrm{m}$. C, Individual bacterial cells embedded in a thin layer of gum around a pit. Bar $=5$ $\mu \mathrm{m}$. D, Large numbers of $X$. fastidiosa in and around pits of adjacent xylem vessel elements. Through the open pit membranes, one can see what appears to be a large aggregate of bacteria in the lumen of the xylem vessel. Bar $=10 \mu \mathrm{m}$. E, Large aggregate of bacteria blocking a simple perforation plate. Bar $=30$ $\mu \mathrm{m}$. F and $\mathbf{G}$, Large numbers of bacteria entirely occluding xylem vessels. Note the loose arrangement of the cells in F (bar $=10 \mu \mathrm{m})$ and the more tightly embedded bacteria in $\mathrm{G}(\mathrm{bar}=10 \mu \mathrm{m})$. 
the sum of all occlusions indicated significant differences for genotype-infection status-tissue $(P=0.0397)$, genotype $(P=$ $0.0399)$, infection status $(P<0.0001)$, and position on the plant was observed for the sum of all occlusions. In water-inoculated plants, significant effects of the genotypetissue $(P=0.0154)$ interaction and the tissue $(\mathrm{P}=0.0015)$ main effect but not the genotype main effect were observed. Although the differences in vessel occlusions of petioles were not significant among the genotypes of control plants, those in stem internodes were significantly greater for $V$. vinifera and $V$. rufotomentosa than $V$. smalliana and $V$. arizonica/candicans (Fig. 2). In $X$. fastidiosa-infected plants, xylem tissue $(P=0.0134)$. No effect of sampling

vessel occlusion differed between genotypes $(P=0.01)$ and tissues $(P<0.0001)$. The average percentage of vessels occluded ranged from $2.1 \%$ in stem internodes and $9.0 \%$ in petioles of $X$. fastidiosa-infected $V$. arizonica/candicans to $34.7 \%$ in stem internodes and $55.9 \%$ in petioles of $V$. vinifera (Fig. 2). For both stem internodes and petioles, intermediate values were observed for $V$. rufotomentosa and $V$. smalliana. Within genotype, $X$. fastidiosa infection strongly increased xylem vessel occlusion in $V$. vinifera $(P=$ $0.0033)$. However, only marginal increases in the percentage of occluded xylem vessels were observed for $X$. fastidiosainfected $V$. smalliana $(P=0.0635)$, V. arizonica/candicans $(P=0.0572)$, and $V$.

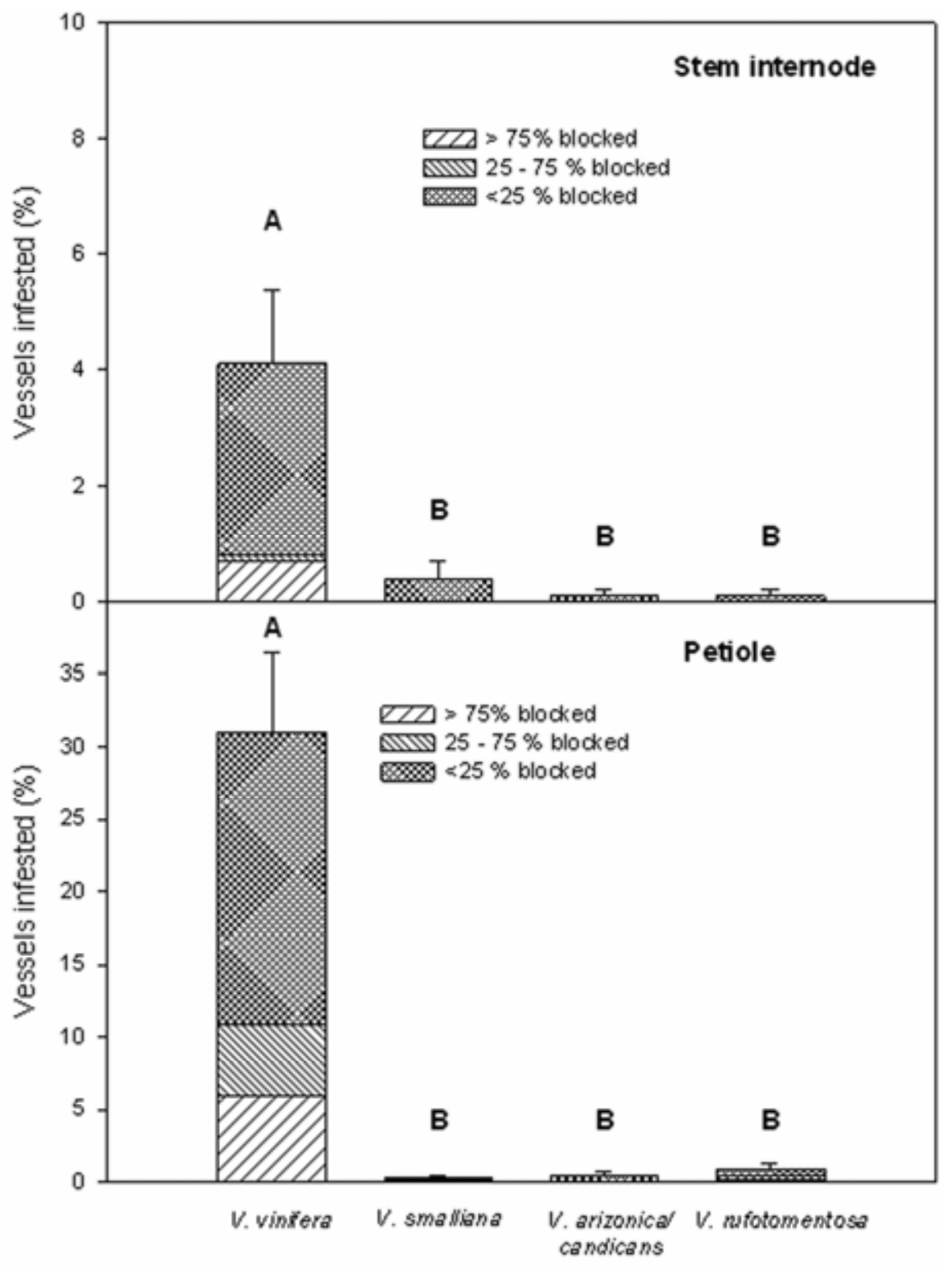

\section{Genotype}

Fig. 4. Comparison of the percentage of Xylella fastidiosa containing xylem vessels among the four grape genotypes examined. The severity of $X$. fastidiosa presence was rated based on the extent of blockage caused in a particular xylem vessel. Error bars indicate the standard error of the means for the total percentage of infested xylem vessels. Different letters between genotypes indicate significant differences in percentage of xylem vessel occlusion within tissue. rufotomentosa $(P=0.1103)$. In order to investigate xylem vessel occlusions in more detail, separate statistical analyses were conducted for $X$. fastidiosa, tyloses, and fibrillar networks and gums, but not for crystals, because they were observed on very rare occasions only.

No $X$. fastidiosa was found in waterinoculated control plants; consequently, those plants were excluded from the analysis for $X$. fastidiosa presence in xylem vessels. $X$. fastidiosa in xylem vessels were observed as individual bacteria and in groups ranging from small clusters to very large aggregates (Fig. 3). In some instances, the bacteria appeared tightly embedded in a matrix whereas, in other instances, bacterial aggregates were loosely arranged. The presence of fibrillar strands connecting neighboring bacterial cells among each other and anchoring bacterial cells to vessel walls were observed frequently. Bacteria often were found on pit membranes or in pits with breached membranes that allowed bacterial movement from one vessel to another. In addition, they were found frequently in crevasses at perforation plates as solitary cells, small clusters, or in larger aggregates.

The presence of $X$. fastidiosa was influenced by genotype $(P<0.0001)$ and tissue $(P=0.0002)$, with a significant interaction effect of genotype-tissue $(P<0.0001)$. The percentage of vessels containing $X$. fastidiosa was greatest in $V$. vinifera for both stem internodes $(4.1 \pm 1.3 \%)$ and petioles $(30.9 \pm 5.6 \%)$ and averaged less than $1 \%$ in both stem internodes and petioles of each of the other three genotypes (Fig. 4). Among the $V$. vinifera samples examined, the maximum percentage of vessels containing $X$. fastidiosa was $11.3 \%$ in stem internodes and $56.7 \%$ in petioles. In the other three genotypes, no more than $2.7 \%$ of the vessels contained $X$. fastidiosa. The majority of $X$. fastidiosa observed were in the form of individual cells or small aggregates that occluded the vessels to less than $25 \%$. In fact, in $V$. aestivalis var. smalliana, $V$. arizonical candicans, and $V$. rufotomentosa stem internodes, no $X$. fastidiosa aggregates occluding vessels to more than $25 \%$ were found. This also was true for $V$. arizonica/candicans petioles. In $V$. smalliana petioles, some vessels $(0.1 \%)$ with medium-size aggregates were observed and, in $V$. rufotomentosa petioles, some vessels with medium $(0.2 \%)$ and large $(0.2 \%)$ aggregates were found (Fig. 4). The percentage of $X$. fastidiosa-infested vessels was significantly $(P<0.05)$ greater in $V$. vinifera petioles than stem internodes. However, in the other three genotypes, the differences between stem internodes and petioles were not significant.

Tyloses. Tyloses were observed in both water- and X. fastidiosa-inoculated plants of all genotypes (Fig. 5). A large range in tylose occlusions of xylem vessels was 
observed. Tyloses were observed as initials barely pushing through pits and as individual or multiple tyloses completely occluding xylem vessels (Fig. 6). Some of the tylose occlusions filled xylem vessels over a considerable length. In some cases, the tyloses originated from single xylem parenchyma cells whereas, in others, multiple xylem parenchyma cells surrounding the xylem vessel formed tyloses.

Tylose formation was significantly influenced by genotype $(P=0.0374)$ and infection status $(P=0.0001)$, and a marginal effect of tissue type $(P=0.0565)$ also was observed. Separate analysis by infection status revealed that tylose formation in the water-inoculated control plants was not significantly affected by the genotype main effect, but that a significant $(P=0.049)$ genotype-tissue interaction and a significant tissue $(P=0.0294)$ effect existed. In contrast, tylose formation was influenced by genotype $(P=0.0142)$ in the $X$. fastidiosa-infected plants. In addition, a significant $(P=0.0008)$ genotype-tissue interaction effect was observed in the $X$. fastidiosa-infected plants. Overall analyses found no significant effect of plant position on tylose formation. Tylose formation was increased in response to $X$. fastidiosa infection in both stem internodes and petioles. Within genotypes, differences in tylose formation between water-inoculated control and $X$. fastidiosa-inoculated plants were significant for $V$. vinifera $(P=$ $0.0009)$ and $V$. smalliana $(P=0.0375)$, but only marginally significant for $V$. rufotomentosa $(P=0.0794)$ and not significant for $V$. arizonica/candicans. In $V$. arizonica/candicans, the mean percentage of vessels occluded by tyloses was $1.25 \%$ (average across tissues and infection status) and the maximum observed among all samples was $6.7 \%$. The percentage of vessels occluded by tyloses was not significantly different between stem internodes and petioles for V. smalliana and $V$. rufotomentosa. The mean vessel occlusion by tyloses in $X$. fastidiosa-inoculated plants was $7.9 \%$ in V. smalliana and $17.4 \%$ in $V$. rufotomentosa, whereas it was 0.9 and $2.1 \%$ in water-inoculated control plants, respectively. In $V$. vinifera, the mean percentage of vessel occlusion by tyloses in stem internodes $(25.0 \%)$ was greater $(P<0.05)$ than in petioles $(8.5 \%)$ and reached a maximum of $42.7 \%$. With the exception of $V$. arizonica/candicans and petioles from water-inoculated $V$. rufotomentosa, for which small tyloses were observed, the majority of tyloses observed occluded the xylem vessels to $>75 \%$. In fact, those tyloses accounted for $61 \%$ of the total found.

Fibrillar networks and gum. The presence of fibrillar networks in xylem vessels was observed in water-inoculated and $X$. fastidiosa-inoculated plants of all genotypes (Fig. 7). These networks typically were attached to vessel walls, sometimes attached around the entire circumference of the vessel or only in some sectors. Aside from the fibrillar nets, vessel occlusions by gum-like material also were observed (Fig. 7). At low magnification, vessel occlusions by gum-like material (Fig. 7A) appeared very similar to occlusions by large aggregates of tightly embedded bacteria (Fig. $3 \mathrm{G})$. However, the occlusions could be differentiated readily after close examination due to different surface appearances and the absence of bacteria in the gum-like material. Fibrillar nets and gum-like occlusions were observed more frequently in $X$. fastidiosa- than in water-inoculated plants $(P=0.0034)$ and in petioles $(3.3 \%)$ than in stem internodes $(<1 \%)(P<0.0001)$. However, because of the low abundance of gum-like occlusions, further statistical analyses were conducted on data pooled with those from the fibrillar networks. Because it was difficult to assess the extent of occlusion of the fibrillar networks, differentiation of the extent of blockage as conducted for the $X$. fastidiosa aggregates and tyloses was not attempted for fibrillar nets or gum. Overall analysis revealed significant effects of infection status $(P=$

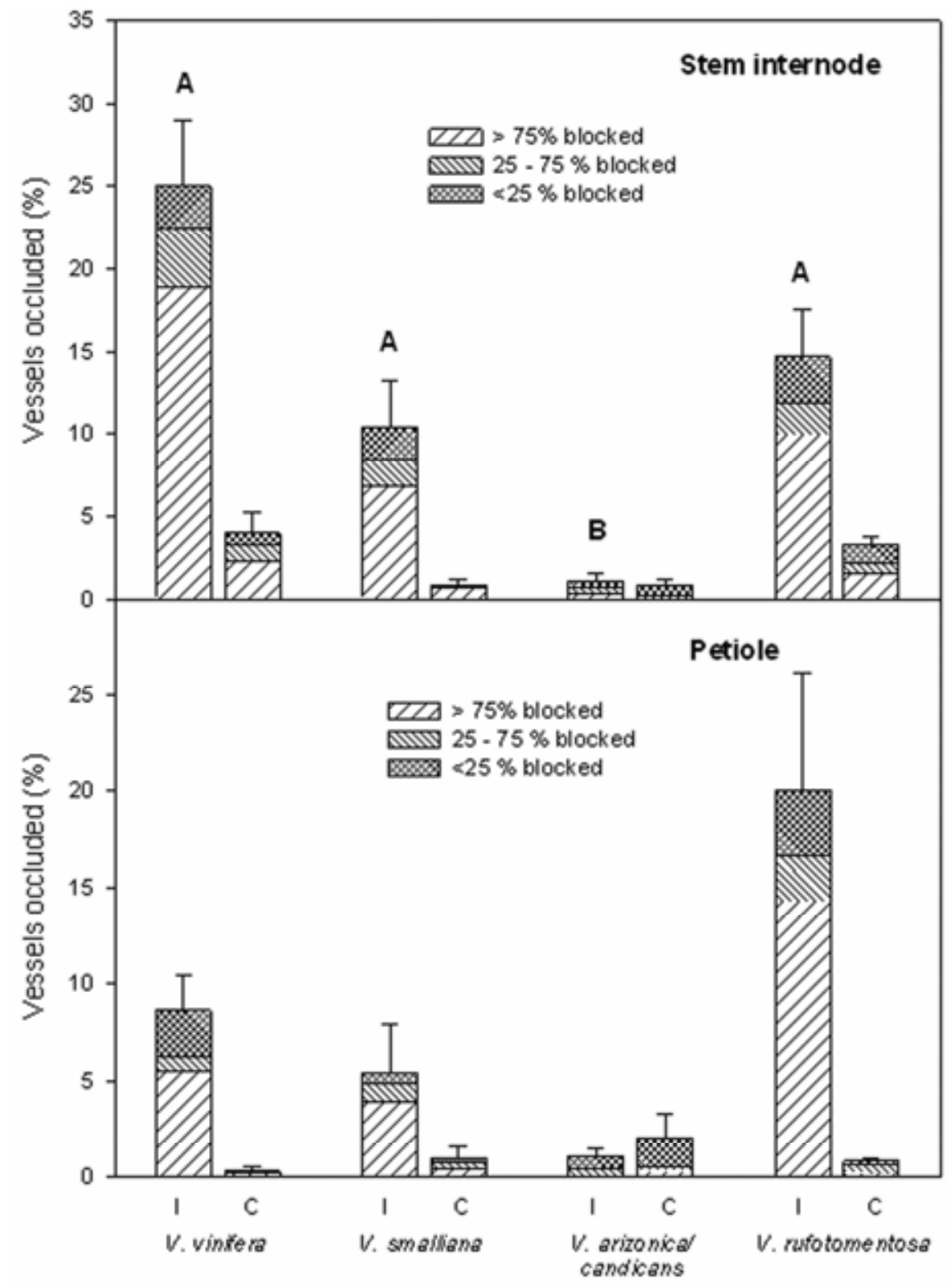

\section{Genotype and Infection Status}

Fig. 5. Comparison of tyloses formation among four grape genotypes inoculated either with water (C) or Xylella fastidiosa (I). The extent of vessel blockage was rated based on the size of the tyloses in a particular xylem vessel. Error bars indicate the standard error of the means for the total of tyloses occluded xylem vessels. Different letters between genotypes indicate significant differences in percentage of xylem vessel occlusion within tissue. Comparisons were made within infection status, capital letters corresponding to infected plants and noncapital letters to control plants. Absence of letters indicates that the differences were not statistically significant among genotypes. 


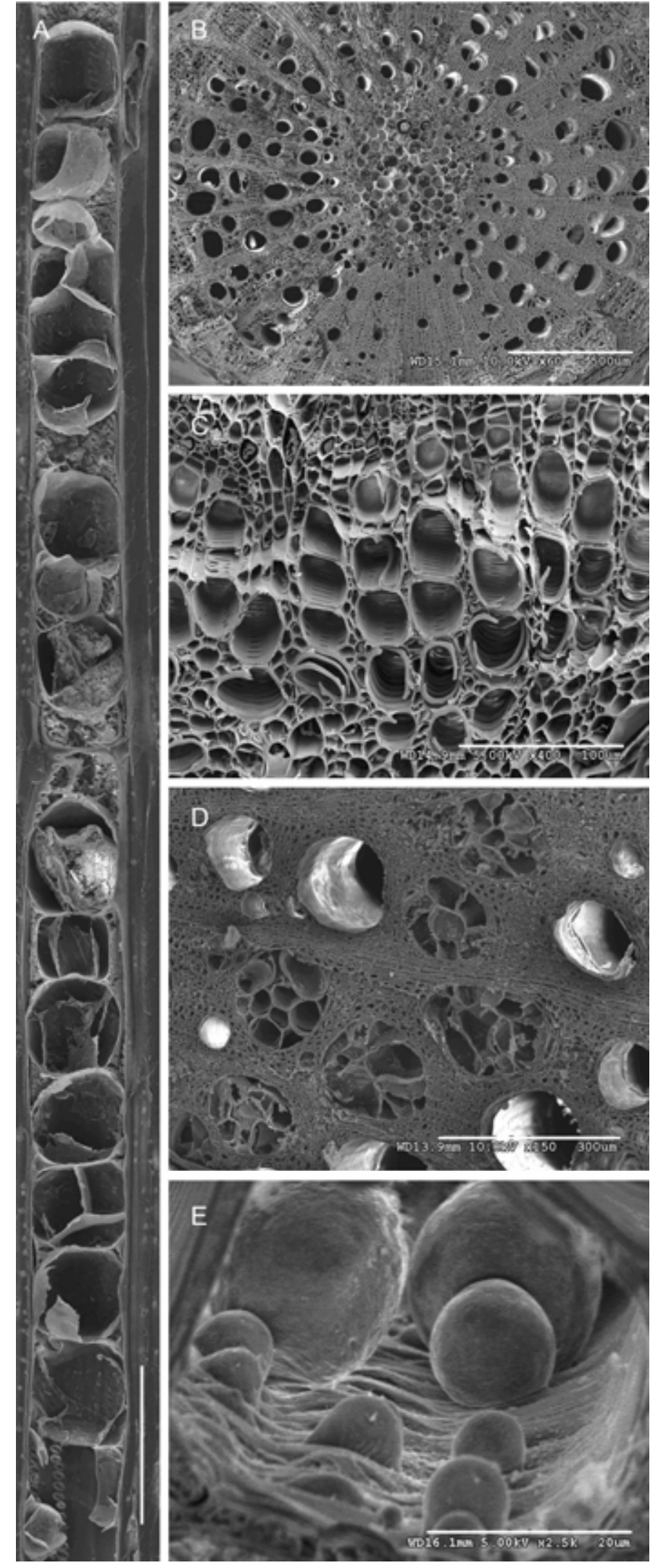

Fig. 6. Scanning electron micrographs of grape internode and petiole xylem. A, Internode from a Xylella fastidiosa-infected Vitis vinifera plant. Longitudinal section through a xylem vessel completely occluded by tyloses. Bar $=100 \mu \mathrm{m}$. $\mathbf{B}$ and $\mathbf{C}$, Low-magnification views of $\mathbf{B}$, an internode (bar $=500$ $\mu \mathrm{m})$ and $\mathbf{C}$, a petiolar vascular bundle (bar $=100 \mu \mathrm{m})$ from a $V$. aestivalis var. rufotomentosa control plant showing predominantly empty lumens of xylem vessels. $\mathbf{D}$ and $\mathbf{E}$, Transverse section of stem internodes of $X$. fastidiosa-inoculated $V$. aestivalis var. rufotomentosa plants. D, Xylem vessel elements completely occluded by advanced stages of tyloses next to vessel elements free of any blockage. $\mathrm{Bar}=300 \mu \mathrm{m}$. E, Tyloses at various stages of development penetrating through the pits from numerous xylem parenchyma cells. Bar $=20 \mu \mathrm{m}$.
$0.0109)$, tissue $(P<0.0001)$, genotypetissue $(P=0.0003)$, and infection statustissue $(P=0.0033)$. A significant genotype effect $(P=0.0275)$ was observed for stem internode results but not for petiole results. Significantly $(P<0.05)$ greater occurrences of nets or gum occlusions were found in $V$. vinifera than in $V$. smalliana for both water- and $X$. fastidiosa-inoculated stem internodes (Fig. 8). In V. smalliana, $V$. arizonica/candicans, and $V$. rufotomentosa, the occurrence of nets or gum occlusions in petiole tissue was significantly greater $(P<0.001)$ than in stem internodes; however, the difference was not significant in $V$. vinifera tissues. Although the overall analysis indicated a significant effect of infection status on net or gum occurrence, individual comparisons within genotypes for each tissue revealed a significant effect only in $V$. vinifera petioles $(P=0.0482)$. However, across all genotypes, 2-fold (stem internodes) and 5.7-fold (petioles) greater occurrences of net or gum occlusions were observed in $X$. fastidiosa- over water-inoculated plants. As indicated by genotype comparison of net or gum occurrence in stem internodes across water- and $X$. fastidiosa-inoculated plants, their presence was observed more often in $V$. vinifera $(3.7 \%)$ than in the other three species $(0.6 \%$; average across species and infection status). However, the differences were not significant in petiole tissues.

Crystals. Intralumenal crystals (Fig. 9) were observed only in three $V$. vinifera cross sections of infected plants. The crystals were identified as such using X-ray microanalysis which showed high concentrations of Ca (Fig. 10). None of the crystals observed were associated with $X$. fastidiosa.

\section{DISCUSSION}

Symptomology and $X$. fastidiosa levels. The symptoms observed on $V$. vinifera were typical for PD, and marginal leaf necrosis such as that observed on $V$. rufotomentosa was consistent with previous reports on PD-resistant genotypes $(18,20$, $24,28,38,50)$. The severity of the symptoms appeared to be correlated with the number of $X$. fastidiosa in that the symptoms were severe in $V$. vinifera, mild in $V$. aestivalis var. rufotomentosa, and inconclusive in $V$. arizonica/candicans and $V$. aestivalis var. smalliana.

In this study, we investigated the influence of $X$. fastidiosa inoculation on xylem vessel colonization and occlusion in petioles and stem internodes among four grape genotypes that differ in the extent to which they support $X$. fastidiosa growth. Krivanek and Walker (24) have shown a high correlation between the field resistance of grape genotypes and ELISA estimates of the number of $X$. fastidiosa in stem tissue. We used neighboring stem internode segments for $X$. fastidiosa quantification by ELISA and SEM analysis of 
xylem vessels. Similarly, $X$. fastidiosa numbers were determined in leaf blades corresponding to the petioles utilized for SEM analysis. ELISA data confirmed that the four grape genotypes used in this study supported differing levels of $X$. fastidiosa (Fig. 1). Chardonnay is known to be highly susceptible to PD and to support high numbers of $X$. fastidiosa $(36,37,39)$ and was selected for this study to serve as a representative of highly susceptible grape genotypes. $V$. arizonica/candicans, $V$. smalliana, and $V$. rufotomentosa were selected based on a parallel study to represent genotypes that support low or intermediate levels of $X$. fastidiosa (11). Indeed, ELISA confirmed that the number of $X$. fastidiosa was greatest in Chardonnay while the concentrations in $V$. arizonica/candicans were always smallest, although not significantly different from $V$. smalliana and V. rufotomentosa (Fig. 1).

Vessel occlusions. Xylem vessel occlusions by $X$. fastidiosa aggregates, tyloses, gum, and fibrillar networks are commonly observed in PD-infected plants $(8,18,20$, $24,28,30,45,52)$. ELISA data not only confirmed the infection status of the plants examined by SEM but also showed the level of bacterial infection and allowed correlation analyses with vessel occlusion data. Indeed, xylem vessel occlusion was highly correlated with $X$. fastidiosa numbers in inoculated plants. Regression analyses revealed positive relationships of $X$. fastidiosa numbers with the total number of occluded xylem vessels (stem internode: $R^{2}=0.45$; petiole: $R^{2}=0.59$ ), as well as with $X$. fastidiosa-infested xylem vessels (stem internode: $R^{2}=0.36$; petiole: $R^{2}=0.50$ ), tyloses formation in xylem vessels (stem internode: $R^{2}=0.27$; petiole: $\left.R^{2}=0.13\right)$, and net or gum occlusions of xylem vessels (stem internode: $R^{2}=0.42$; petiole: $R^{2}=0.13$ ). In petiole tissues, the number of occlusions observed in control plants did not differ among genotypes, either for individual occlusions or as the sum of all occlusions (Figs. 3, 6, and 7). In stem internodes of control plants, significant genotypic differences were observed for the sum of all occlusions, predominantly a consequence of significant differences in the frequency of fibrillar networks or gums between $V$. vinifera and $V$. smalliana (Figs. 2 and 8). Vessel occlusions such as those observed in this study have been documented to occur at low levels in control plants $(4,8,40,41)$. On average across genotypes, $4.3 \%$ of petiole and $3.5 \%$ of internode vessels were occluded in the control plants. The occurrence of tyloses and mucilage generally is accepted to be a function of normal aging, injury, or infection by vascular pathogens $(4,40$, 42,51). The reasons for the significant differences in the occurrence of occlusions between control plants of $V$. vinifera and $V$. smalliana are unclear. Genotype-specific responses to mechanical wounding caused by the inoculation of control plants with water and to periodic pruning conducted to increase light penetration and air circulation in the canopy may have contributed to these differences in the control plants.

In internodes of $X$. fastidiosa-inoculated plants, significant genotypic differences were observed in respect to total percentage of occluded vessels, $X$. fastidiosainfested vessels, tyloses, and fibrillar networks and gums. In petioles, significant differences among genotypes were found for $X$. fastidiosa and the sum of all occlusions (Figs. 2, 4, 5, and 8). In general, when significant differences among genotypes were observed, $V$. vinifera exhibited the greatest and either $V$. smalliana or $V$. arizonica the smallest number of occluded vessels. Within a genotype, $X$. fastidiosa inoculation had a very strong effect on the sum of all vessel occlusions in $V$. vinifera internodes and petioles and in $V$. smalliana internodes. Tendencies for a greater number of occluded vessels in X. fastidiosainfected than in control plants also were present in the petioles of $V$. smalliana and internodes and petioles of $V$. arizonica/candicans and $V$. rufotomentosa. The absence of a significant response or only limited response observed in $V$. arizonica/candicans, $V$. smalliana, and $V$. rufotomentosa compared with $V$. vinifera contrasts with results obtained by Mollenhauer and Hopkins (30) for M. rotundifolia and M. munsoniana. They reported that $X$. fastidiosa-infected plants of those two species exhibited greater frequency of
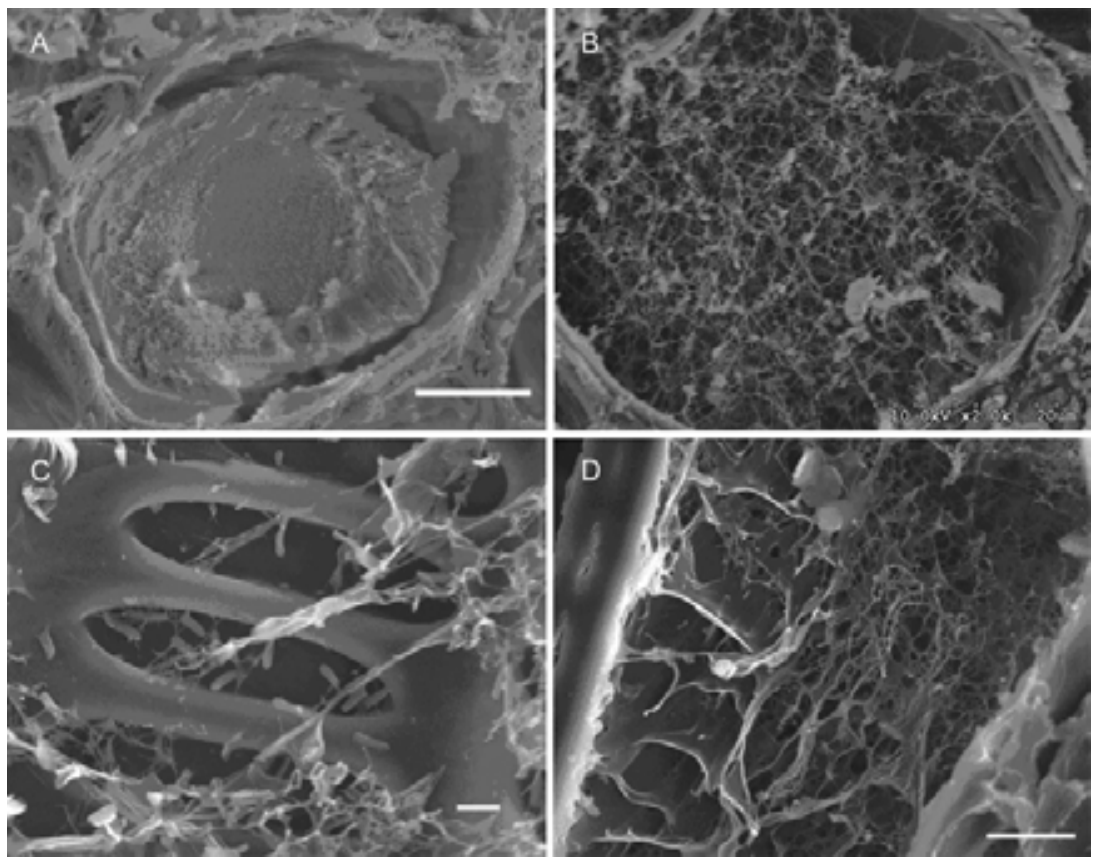

Fig. 7. Scanning electron micrographs of xylem vessel occlusions by gum and fibrillar networks. A, Plug presumed to be gum completely blocks a xylem vessel. Bar $=10 \mu \mathrm{m}$. B, Fibrillar net spanning across the lumen of a xylem vessel. No bacterial cells can be identified in the net. C, Fibrillar net associated with Xylella fastidiosa attached to the xylem wall. Bar $=2 \mu \mathrm{m}$. D, Large fibrillar network filling the lumen of a xylem vessel. Note the sheet-like forms and clumps making up part of this network. Bar $=5 \mu \mathrm{m}$. Micrographs $\mathrm{C}$ and $\mathrm{D}$ were obtained from lyophilized rather than critical-pointdried specimens. tyloses and gums than the $V$. vinifera cv. Thompson Seedless. They suggested that gums and tyloses may be involved in the resistance mechanism of these genotypes by limiting the spread of the infection. Similarly, Huang et al. (22) reported fewer electron-dense occlusions in the susceptivinifera 'French Colombard' than $M$. that these vascular occlusions halt $X$. fas tidiosa infection, thus playing a key role in limiting PD expression in M. rotundifolia. Recently, Krivanek et al. (24) compared resix Vitis genotypes considered to be field cultivars. Although they observed significantly lower tyloses occlusion in internodes of resistant than susceptible genotypes, this was not the case for gum occlusions, and they did not find a strong correlation between vascular occlusions and the PD resistance status of the investigated genotypes. However, in this study, we observed strong positive relationships vessel occlusions with $X$. fastidiosa centrations. Tylose formation in internodes of infected plants was significantly lower in the resistant $V$. arizonica/candicans than in the susceptible $V$. vinifera. The frequency of fibrillar networks and gums was significantly lower in the internodes of ble $V$. vinifera. The susceptismalliana and $V$. arizonica/candicans contrasted with those documented for $M$. rotundifolia $(22,30)$, which indicates differ- 


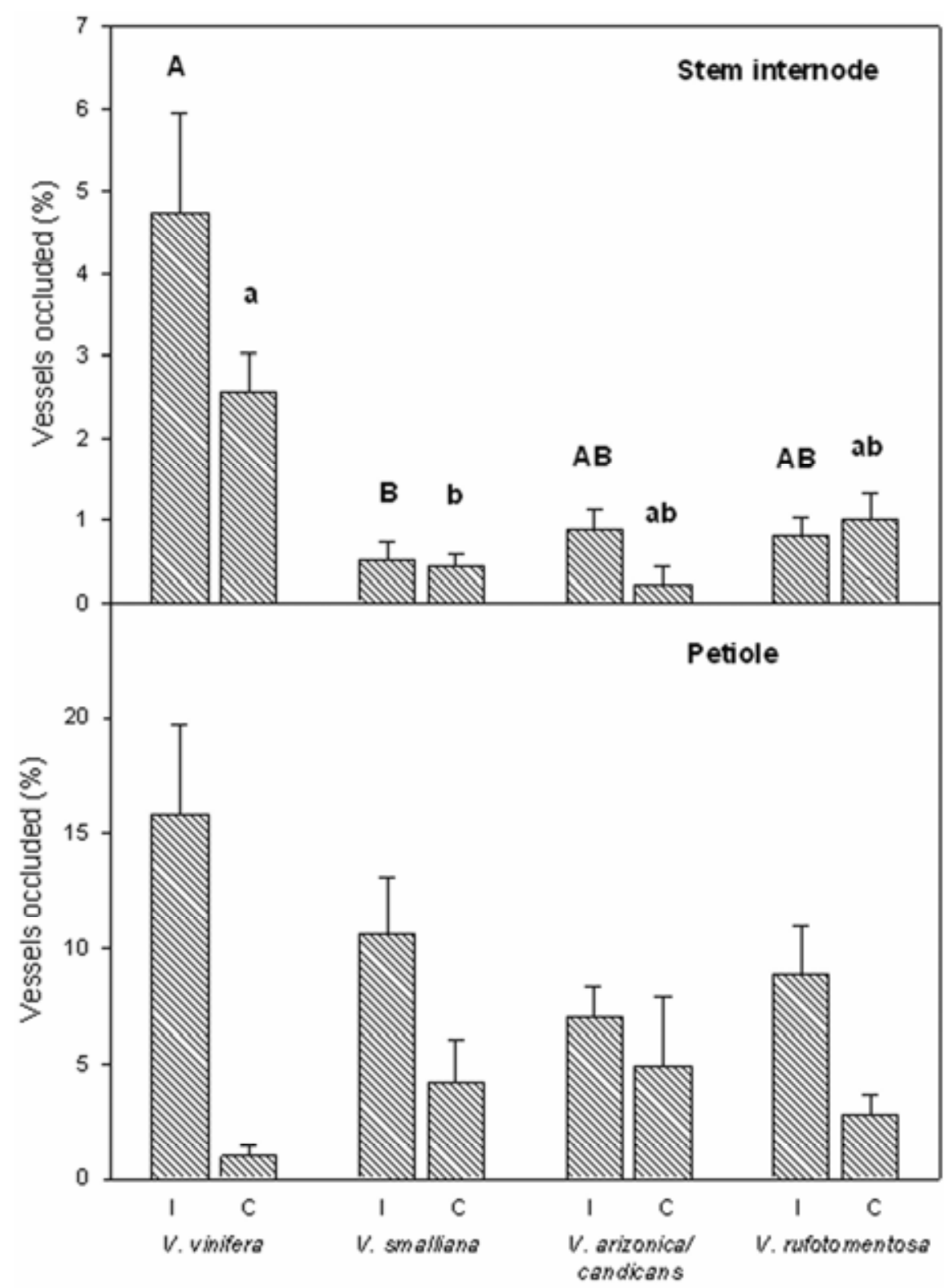

Genotype and Infection Status

Fig. 8. Comparison of fibrillar net and gel formation among four grape genotypes inoculated either with water (C) or Xylella fastidiosa (I). Error bars indicate the standard error of the means. Different letters between genotypes indicate significant differences in percentage of xylem vessel occlusion within tissue. Comparisons were made within infection status, capital letters corresponding to infected plants and noncapital letters to control plants. Absence of letters indicates that the differences were not statistically significant among genotypes.

ent responses to $X$. fastidiosa infection and possibly different roles and contributions of vascular occlusions in respect to PD resistance. Similarly, the variations in responses observed among $V$. arizonical candicans, V. smalliana, and V. rufotomentosa may indicate different levels of tolerance or alternative resistance mechanisms.

In this study, temporal dynamics of the progression of vascular occlusions were not investigated. The time frames involved in the formation of vascular occlusions could have important implications with respect to disease development. For exam- rufotomentosa (Fig. 6; >75\% blocked). Although the large number of advanced tyloses suggests that the onset of tylose formation likely was weeks earlier, the occurrence of tylose initials and mediumsized tyloses indicates continued initiation in stems and petioles. However, the rate of tylose initiation likely changes over time. If tylose formation had a role in limiting the spread of the bacteria throughout the plant, one would expect the induction of tylose formation to occur soon after and in the vicinity of the inoculation event. However, in this study, we did not observe any differences in tylose frequency between the bottom third (includes the site of inoculation) and the middle and top thirds of the plants. Similarly, the frequency with which $X$. fastidiosa-infected vessels were observed did not differ among plant positions, indicating that the spread of the bacteria was not limited by tyloses or other forms of occlusions. X. fastidiosa bacteria were observed in the bottom, middle, and top sections of all infected plants, suggesting systemic infection in all genotypes. The absence of differences in tyloses among the plant positions could be a result of the advanced infection status. It may be that differences could have been detected if analyses had been conducted earlier. On the other hand, recent evidence indicates open connections among xylem vessels over long distances, providing unimpeded pathways for the spread of $X$. fastidiosa across multiple internodes and into leaves throughout $V$. vinifera and $M$. rotundifolia plants $(3,50)$. Thus, the distribution of bacteria at the time of inoculation could range across multiple nodes and result in tylose formation in an area far removed from the site of inoculation. However, Although passive movement over long distances is possible and likely, observation of $X$. fastidiosa in plant tissues that developed post inoculation and the appearance of $X$. fastidiosa colonies and their sizes suggest successful systemic infection in all genotypes, which could not be avoided by tyloses, fibrillar nets, or gel occlusions of the xylem conduits. X. fastidiosa-infested vessels were observed much more frequently in $V$. vinifera than in the other three genotypes (Fig. 4). However, in internodes of $V$. smalliana, $V$. arizonica/candicans, and V. rufotomentosa, $X$. fastidiosa aggregates completely occluding the xylem vessels were never observed. In most cases, the bacterial cells were observed either as individual cells or in aggregates attached to the cell walls, rather than blocking entire vessels. Thus, the direct effect of $X$. fastidiosa aggregate vessel occlusion appears to be of minor importance in limiting the water conduit. The effect of $X$. fastidiosa-generated signals resulting in the induction of tylose formation or fibrillar nets or gel is of greater consequence to water transport in the xylem conduit. 


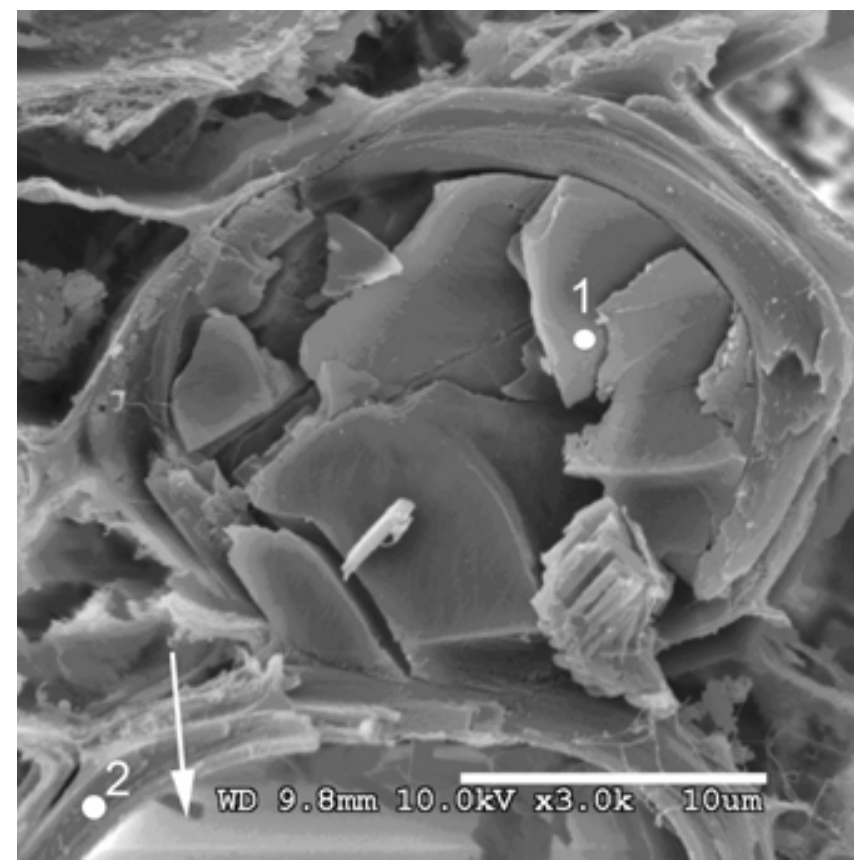

Fig. 9. Scanning electron micrograph of a transverse internode section from a Xylella fastidiosa infected $V$. vinifera plant. The xylem vessel is completely blocked by a calcium-containing crystal (1). Secondary cell wall (2) of a xylem vessel is free of occlusion (arrow).

Fibrillar networks were observed more frequently in petioles than in internodes. The chemical nature of these networks is unclear. At least those present in waterinoculated control plants should be of plant origin. In $X$. fastidiosa-inoculated plants, the networks often were observed together with bacteria, but bacteria were not always present. Thus, it cannot be excluded that some or parts of the networks observed in $X$. fastidiosa-inoculated plants may be of bacterial origin. Similar fibrillar occlusions have been observed in $X$. fastidiosainfected plants by others using SEM $(1,2,13)$. Although of unknown origin and nature, it is likely that these fibrillar networks are dehydrated gels. The pattern of occurrence is consistent with those observed for gels and gums by others $(8,22,24,30,44)$. In addition, transmission and cryoscanning electron micrographs of xylem vessel mucilage by Crews et al. (4) show fibrils and mucilage freezing pattern similar to the fibrillar networks we observed. Rioux et al. (40) found evidence that gel formation in trees is accompanied by the secretion of pectin, which exhibits fibrillar pattern. Pectic polysaccharides are known to form gels (5) and may be the main component of the fibrillar networks observed in this study. Fibrillar networks such as those illustrated in Figures $3 \mathrm{~B}$ and 7C may or may not be of different origin. Figure 3B illustrates an example where the network appears to be localized to a small aggregate and the fibrils connect individual bacterial cells. In contrast, the network shown in Figure 7C spans the lumen of the xylem vessel and is not as closely associated with the bacterial cells. Due to the different sample preparation protocols employed, it is unclear whether this variation in appearance is related to differences in origin or chemical composition or both.

It is unlikely that the crystals observed occluding xylem vessels in infected $V$. vinifera plants are related to the disease. Although none of them were observed in control plants, they were very rare and never associated with any $X$. fastidiosa. Tyson et al. (52) previously reported the rare occurrence of Ca-containing crystals in $X$. fastidiosa-infected plants and also considered it unlikely that they were of importance in respect to PD. The observed crystals may be calcium-oxalate based because calcium-oxalate crystals are the most common crystals found in plants (9).

The four grape genotypes differed in their response to $X$. fastidiosa infection. The percentage of occluded vessels per stem internode cross section averaged $34.7,15.7,11.5$, and $2.1 \%$ for $V$. vinifera, $V$. rufotomentosa, $V$. smalliana, and $V$. arizonica/candicans, respectively. However, the significance of those occlusions in respect to water transport is unclear. For instance, Hopkins (18) showed that analysis of serial sections revealed a 4- to 12fold greater number of occluded vessels than single cross-section analysis. In $V$. vinifera, massive tyloses were not uncommon and some of them extended for more than $1 \mathrm{~mm}$ in length in a single vessel (Fig. $6)$. Thus, it can be argued that the effective number of vessels occluded likely is considerably greater than indicated by single cross-section counts. However, a threshold level at which the occlusion percentage becomes relevant for the water supply of the tissue apical to the occlusion has not been established. Further investigations

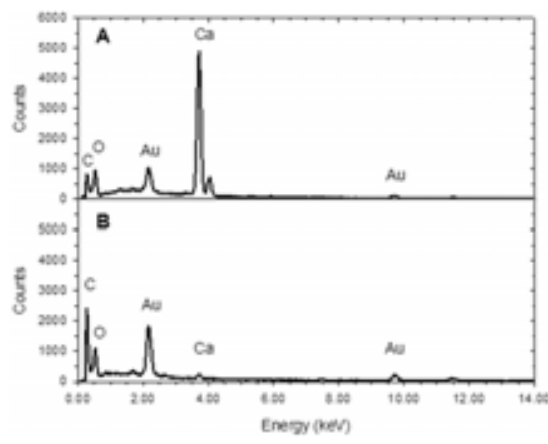

Fig. 10. X-ray spectra collected from the transverse internode section. A, X-ray spectrum from the center of the calcium-containing crystal (Fig. 9, label 1). B, Control X-ray spectrum from the secondary cell wall (Fig. 9, label 2) of a xylem vessel.

into the effect of vessel occlusions on water transport in the stems and the relationship to disease symptom expression would be of interest. Although the positive relationship of symptom development and xylem vessel occlusion could suggest a causative relationship, so could bacterial factors because symptom development also was positively related to the number of $X$. fastidiosa-infected vessels.

Based on the results obtained in this study, it does not appear that the greater resistance or tolerance of $V$. arizonica/candicans, $V$. smalliana, and $V$. rufotomentosa are related to an ability to limit the spread of the infection. It has been suggested by others that this resistance mechanism may occur in $M$. rotundifolia and M. munsoniana $(22,30)$; therefore, it is likely that the three species examined here have different mechanisms of resistance. In addition, based on the number and distribution of $X$. fastidiosa in $V$. arizonica/candicans, V. smalliana, and $V$. rufotomentosa, it possible that the mechanisms of resistance are different or at least expressed to a different extent. Because only the frequency and quantity but not the location of $X$. fastidiosa observations differed among $V$. vinifera and the other three genotypes, it seems more likely that factors influencing $X$. fastidiosa reproductive success or virulence confer greater tolerance or resistance to $V$. arizonica/candicans, $V$. smalliana, and $V$. rufotomentosa.

\section{ACKNOWLEDGMENTS}

Funding for this research was provided by the University of California Pierce's Disease Research Grant Program. We thank D. Margosan for helpful advice and discussions.

\section{LITERATURE CITED}

1. Alves, E., Kitajima, E. W., and Leite, B. 2003. Interaction of Xylella fastidiosa with different cultivars of Nicotiana tabacum: a comparison of colonization patterns. J. Phytopathol 151:500-506.

2. Alves, E., Marucci, C. R., Lopes, J. R. S., and Leite, B. 2004. Leaf symptoms on plum, coffee and citrus and the relationship with the extent of xylem vessels colonized by Xylella fas 
tidiosa. J. Phytopathol. 152:291-297.

3. Chatelet, D. S., Matthews, M. A., and Rost, T. L. 2006. Xylem structure and connectivity in grapevine (Vitis vinifera) shoots provide a passive mechanism for the spread of bacteria in grape plants. Ann. Bot. 98:483-494.

4. Crews, L. J., McCully, M. E., and Canny, M. J. 2003. Mucilage production by wounded xylem tissue of maize roots - time course and stimulus. Funct. Plant Biol. 30:755-766.

5. Darvill, A., McNeil, M., Albersheim, P., and Delmer, D. P. 1980. The primary cell walls of flowering plants. Pages 91-162. in: The Biochemistry of Plants. N. E. Tolbert, ed. Academic Press, New York.

6. Davis, M. J., Purcell, A. H., and Thomson, S. V. 1978. Pierce's disease of grapevines: isolation of the causal bacterium. Science 199:7577.

7. Davis, M. J., Purcell, A. H., and Thomson, S. V. 1980. Isolation media for the Pierce's disease bacterium. Phytopathology 70:425-429.

8. Esau, K. 1948. Anatomic effects of the viruses of Pierce's disease and phony peach. Hilgardia 18:423-482.

9. Fahn, A. 1990. Plant Anatomy. Butterworth Heinemann, Oxford.

10. French, W. J., and Stassi, D. L. 1978. Response of phony-infected peach trees to gibberellic acid. Hortscience 13:158-159.

11. Fritschi, F. B., Lin, H., and Walker, M. A. 2006. Xylella fastidiosa population dynamics in grapevines differing in susceptibility to Pierce's disease. Am. J. Enol. Viticult. 2007 (58:3)

12. Fry, S. M., and Milholland, R. D. 1990. Multiplication and translocation of Xylella fastidiosa in petioles and stems of grapevine resistant, tolerant, and susceptible to Pierce's disease. Phytopathology 80:61-65.

13. Gardner, J. M., Feldman, A. W., and Stamper, D. H. 1983. Role and fate of bacteria in vascular occlusions of citrus. Physiol. Plant Pathol. 23:295-309.

14. Gerrath, J. M., Posluszny, U., and Dengler, N. G. 2001. Primary vascular patterns in the Vitaceae. Int. J. Plant Sci. 162:729-745

15. Goodwin, P. H., DeVay, J. E., and Meredith, C. P. 1988a. Physiological responses of Vitis vinifera cv. 'Chardonnay' to infection by the Pierce's disease bacterium. Physiol. Mol. Plant Pathol. 32:17-32

16. Goodwin, P. H., DeVay, J. E., and Meredith, C. P. 1988b. Roles of water stress and phytotoxins in the development of Pierce's disease of the grapevine. Physiol. Mol. Plant Pathol. 32:1-15.

17. Hopkins, D. L. 1976. Pierce's disease of grapevines. Am. Wine Soc. J. 8:26-27.

18. Hopkins, D. L. 1981. Seasonal concentration of the Pierce's disease bacterium in grapevine stems, petioles, and leaf veins. Phytopathology 71:415-418.

19. Hopkins, D. L. 1989. Xylella fastidiosa: xylem-limited bacterial pathogen of plants. Annu. Rev. Phytopathol. 27:271-290.

20. Hopkins, D. L., Mollenhauer, H. H., and Mortensen, J. A. 1974. Tolerance to Pierce's disease and the associated rickettsia-like bacterium in muscadine grape. J. Am. Soc. Hortic.
Sci. 99:436-439.

21. Hopkins, D. L., and Purcell, A. H. 2002. Xylella fastidiosa: cause of Pierce's disease of grapevine and other emergent diseases. Plant Dis. 86:1056-1066.

22. Huang, P.-Y., Milholland, R. D., and Daykin, M. E. 1986. Structural and morphological changes associated with the Pierce's disease bacterium in Bunch and Muscadine grape tissues. Phytopathology 76:1232-1238.

23. Krivanek, A. F., Stevenson, J. F., and Walker, M. A. 2005. Development and comparison of symptom indices for quantifying grapevine resistance to Pierce's Disease. Phytopathology 95:36-43.

24. Krivanek, A. F., and Walker, M. A. 2005. Vitis resistance to Pierce's disease is characterized by differential Xylella fastidiosa populations in stems and leaves. Phytopathology 95:44-52.

25. Lee, R. F., Raju, B. C., Nyland, G., and Goheen, A. C. 1982. Phytotoxin(s) produced in culture by the Pierce's disease bacterium. Phytopathology 72:886-888.

26. McElrone, A. J., Sherald, J. L., and Forseth, I. N. 2001. Effects of water stress on symptomatology and growth of Parthenocissus quinquefolia infected by Xylella fastidiosa. Plant Dis. 85:1160-1164.

27. McElrone, A. J., Sherald, J. L. , and Forseth, I. N. 2003. Interactive effects of water stress and xylem-limited bacterial infection on the water relations of a host vine. J. Exp. Bot. 54, no. 381:419-430

28. Milholland, R. D., Huang, P. Y., Clayton, C. N., and Jones, R. K. 1981. Pierce's disease on muscadine grapes in North Carolina USA. Plant Dis. 65:73-74.

29. Mircetich, S. M., Lowe, S. K., Moller, W. J., and Nyland, G. 1976. Etiology of almond leaf scorch disease and transmission of the causal agent. Phytopathology 66:17-24.

30. Mollenhauer, H. H., and Hopkins, D. L. 1976. Xylem morphology of Pierce's diseaseinfected grapevines with different levels of tolerance. Physiol. Plant Pathol. 9:95-100.

31. Mortensen, J. A., Stover, L. H., and Balerdi, C. F. 1977. Sources of resistance to Pierce's disease in Vitis. J. Am. Soc. Hortic. Sci. 102:695697.

32. Mullins, M. G., Bouquet, A., and Williams, L. E. 1992. Biology of the Grapevine. Cambridge University Press, Cambridge.

33. Perring, T. M., Farrar, C. A., and Blua, M. J. 2001. Proximity to citrus influences Pierce's disease in Temecula valley vineyards. Calif. Agric. 55, no. 4:13-18.

34. Pratt, C. 1974. Vegetative anatomy of cultivated grapes-a review. Am. J. Enol. Viticult. 25:131-150.

35. Pratt, C. 1978. Shoot nodes of Vitis labruscana Bailey cv. Concord. Vitis 17:329-334.

36. Purcell, A. H. 1974. Spatial patterns of Pierce's disease in the Napa Valley. Am. J. Enol. Viticult. 25 , no. 3:162-167.

37. Purcell, A. H. 1981. Vector preference and inoculation efficiency as components of resistance to Pierce's disease in European grape cultivars. Phytopathology 71:429-435.

38. Purcell, A. H. 1986. Pierce's disease. Pages 62-
69 in: Grape Pest Management. D. L. Flaherty, ed. Cooperative Extension University of California, Division of Natural Resources, Oakland.

39. Raju, B. C., and Goheen, A. C. 1981. Relative sensitivity of selected grapevine cultivars to Pierce's disease bacterial inoculations. Am. J. Enol. Viticult. 32:155-158

40. Rioux, D., Nicole, M., Simard, M., and Ouellette, G. B. 1998. Immunocytochemical evidence that secretion of pectin occurs during gel (gum) and tylosis formation in trees. Phytopathology 88:494-505.

41. Roussel, S., Nicole, M., Lopez, F., Ricci, P. Geiger, J.-P., Renard, M., and Brun, H. 1999. Leptosphaeria maculans and cryptogein induce similar vascular responses in tissues undergoing the hypersensitive reaction in Brassica napus. Plant Sci. 144:17-28.

42. Rudelle, J., Octave, S., Kaid-Harche, M. Roblin, G., and Fleurat-Lessard, P. 2005. Structural modifications induced by Eutypa lata in the xylem of trunk and canes of Vitis vinifera. Funct. Plant Biol. 32:537-547.

43. Ruel, J. J., and Walker, M. A. 2006. Resistance to Pierce's disease in Muscadinia rotundifolia and other native grape species. Am. J. Enol Viticult. 57:158-165.

44. Ruzin, S. E. 1999. Plant Microtechnique and Microscopy. Oxford University Press, New York.

45. Stevenson, J. F., Matthews, A. M., Greve, L. C., Labavitch, J. M., and Rost, T. L. 2004 Grapevine susceptibility to Pierce's disease II: progression of anatomical symptoms. Am. J. Enol. Viticult. 55:238-245.

46. Stevenson, J. F., Matthews, A. M., and Rost, T. L. 2004. Grapevine susceptibility to Pierce's disease I: relevance of hydraulic architecture. Am. J. Enol. Viticult. 55:228-237.

47. Stevenson, J. F., Matthews, M. A., and Rost, T. L. 2005. The developmental anatomy of Pierce's disease symptoms in grapevines: green islands and matchsticks. Plant Dis. 89:543-548

48. Stoner, W. N., Stover, L. H., and Parris, G. K. 1951. Field and laboratory investigations indicate grape degeneration in Florida due to Pierce's disease virus infection. Plant Dis. Rep. 35:341-344.

49. Thorne, E. T., Stevenson, J. F., Rost, T. L., Labavitch, J. M., and Matthews, M. A. 2006. Pierce's disease symptoms: comparison with ymptoms of water-deficit and the impact of water-deficits. Am. J. Enol. Viticult. 57:1-11.

50. Thorne, E. T., Young, B. M., Young, G. M. Stevenson, J. F., Labavitch, J. M., Matthews, M. A., and Rost, T. L. 2006. The structure of xylem vessels in grapevine (Vitaceae) and a possible passive mechanism for the systemic spread of bacterial disease. Am. J. Bot. 93:497-504.

51. Tyree, M. T., and Zimmermann, M. H. 2002. Xylem Structure and the Ascent of Sap. Springer.

52. Tyson, G. F., Stojanovic, B. J., Kuklinski, R F., DiVittorio, T. J., and Sullivan, M. L. 1985 Scanning electron microscopy of Pierce's disease bacterium in petiolar xylem of grape leaves. Phytopathology 75:264-269. 